Saeculum Christianum

t. XXVII $\bullet 2 / 2020$

s. $74-88$

MARIA ROWIŃSKA-SZCZEPANIAK ${ }^{1}$

Uniwersytet Opolski

ORCID: 0000-0003-2669-8681

\title{
CZY NA PEWNO UT SUPRA? SYLWETKA DUCHOWA ŚW. JANA Z KĘT W PARENETYCZNEJ NARRACJI FABIANA BIRKOWSKIEGO
}

\section{Is it Ut supra for sure? The spiritual profile of Saint Jan of Kęty in the parenetic narration of Fabian Birkowski \\ Abstract}

The article is an attempt at reconstructing the spiritual profile of St. Jan of Kęty, which emerges from the speech in Latin delivered by Fabian Birkowski. In his literary narration, the $17^{\text {th }}$-century preacher referred, among others, to the words Ut supra, which were meant to constitute the life motto of the medieval Professor. Attributing the above expression to Jan of Kęty, however, was erroneous. As it is proved in the present text, the mistake resulted from a wrong understanding of these words in the reading of the translation of Kronika (Chronicle) by Maciej Miechowita, which - in turn - Piotr Skarga attached to Żywot (The Life) of the Saint. This mistake is significant insofar as it was made by other authors, too; in consequence the expression is inscribed in the history of the Krakow Professor's cult.

Keywords: hagiography, preaching, parenetics, Fabian Birkowski, Saint Jan of Kęty

\section{Streszczenie}

Artykuł stanowi próbę rekonstrukcji duchowej sylwetki św. Jana z Kęt, jaka wyłania się z poświęconej mu łacińskiej mowy Fabiana Birkowskiego. W swojej literackiej narracji XVII-wieczny kaznodzieja odwołuje się m.in. do mających stanowić życiową dewizę średniowiecznego profesora słów Ut supra. Przypisywanie Janowi z Kęt powyższego wyrażenia było jednak błędem. Jak wykazane zostaje w niniejszym tekście, wynikał on z niewłaściwego odczytania wspomnianych słów podczas lektury tłumaczenia Kroniki Macieja Miechowity, które Piotr Skarga dołączył do Żywotu świętego. Błąd ten jest o tyle istotny, że popełnili go również inni twórcy, przez co słowa te wpisały się w dzieje kultu krakowskiego profesora.

Słowa kluczowe: hagiografia, kaznodziejstwo, parenetyka, Fabian Birkowski, św. Jan z Kęt

\footnotetext{
1 Maria Rowińska-Szczepaniak - dr hab., pracownik badawczo-dydaktyczny w Instytucie Nauk o Literaturze Uniwersytetu Opolskiego. Zajmuje się literaturą i kulturą epok dawnych, zwłaszcza hagiografią, kaznodziejstwem XVI i XVII wieku, poezją barokową oraz problematyką ciągłości tradycji dawnej Polski. E-mail: mrowinska@uni. opole.pl.
} 


\section{W blasku podobieństwa - wprowadzenie}

Va Boga jeszcze patrzyć nie możem, ale obrazem jego ucieszyć się możem"2 - przy, 9. pominał autor pierwszego polskiego zbioru hagiograficznego Piotr Skarga i, wyjaśniając czytelnikowi w jaki sposób jest to możliwe, wskazywał na świętych: „są obrazem Boga żywego; o jako pięknie i miło na nie patrzyć! Święci malowaną twarz Boską cnotami Boskimi i od Boga wlanemi na sobie mają; o jako wdzięczny to obraz, o jako oczy wiernych uwesela"3.

Liczne zatem przykłady form twórczości hagiograficznej, tak charakterystycznej dla kultury chrześcijańskiej, są źródłem poznania tego samego bohatera, ale za pomocą różnych obrazów. Przedstawiane w tekstach biografie świętych postaci - „przyczyńców”, jak je określa Skarga, w wypraszaniu łask u Boga - stanowić mają dla odbiorcy zachętę do naśladownictwa, z możliwością wyboru wzorca odpowiadającego konkretnemu powołaniu. Aleksandra Witkowska OSU, dokonując oceny dotychczasowych osiągnięć badawczych i edytorskich w zakresie hagiografii, dostrzega potrzebę ponownego sięgania po materiały źródłowe, by - jak stwierdza - ,pokazać żywych ludzi, będących autentycznymi znakami owocności Kościoła”, a działaniom tym winien towarzyszyć „obiektywizm i miłość prawdy, poszukiwanie prawdziwego obrazu człowieka, będącego odbiciem świętości Boga"4. Ten głos badaczki podtrzymuje m.in. Ignacy Kosmana OFMConv, gdy - rozpatrując kwestię skuteczności oddziaływania hagiografii (za przedmiot analizy obierając kaznodziejstwo) zachęca również do zainteresowania się źródłami dotyczącymi osób, które zostały wyniesione na ołtarze, co ma pozwolić na ukazanie ich w ,egzystencjalnej pełni, w sposób nieszablonowy i ubogacający słuchaczy" ". Ważne dla rozważań autora jest określenie istoty świętości, wyjaśnia więc, że: „stanowi swoisty obraz - ikonę Boga na ziemi. Tak jak ikona, podobnie i homilia hagiograficzna stanowi okno, przez które widać, jak konkretne ludzkie życie przechodzi w wymiar nadprzyrodzony; staje się obrazem Boga. Dzięki takiemu ikonograficznemu - podejściu homilia staje się obrazowa, a święty jest na tyle konkretny i ludzki, że zachęca do pójścia w jego ślady"'.

W kontekście tego - jak się okazuje - niezmiennego przesłania hagiograficznego, w niniejszym szkicu przywołane zostanie jedno ze źródeł piśmiennictwa dawnej Polski. Choć rozważania rozpoczynają się słowami Piotra Skargi, skierowanymi do czytelnika Żywotów świętych, to jednak przedmiotem analizy będzie tekst autorstwa innego staropolskiego kaznodziei - dominikanina Fabiana Birkowskiego ${ }^{7}$. Uczcił on Skargę mową pogrzebową i jako

P. Skarga, Do Czytelnika dobrej wolej, w: idem, Żywoty świętych Starego i Nowego Zakonu, Kraków 1605 , s. 1. Ibidem.

4 A. Witkowska, Polska twórczość hagiograficzna. Próba bilansu, „Anamnesis”, 11/2005, nr 40, s. 109. Por. R. Prejs, Hagiografia polska. Najnowsze osiagnięcia, „Studia Nauk Teologicznych”, 6-7/2011-2012, s. 101-107.

5 I. Kosmana, Homilia hagiograficzna pót wieku po „Vaticanum II,, „Studia Koszalińsko-Kołobrzeskie”, 20/2013, nr 1-2, s. 75. Por. W. Świerzawski, Homilia hagiograficzna, w: Kanonizacje a nowa ewangelizacja. Sympozjum naukowe z okazji 30-lecia Instytutu Liturgicznego, Kraków 2000, s. 211-218; K. Panuś, Chrystocentryczne przepowiadanie hagiograficzne, w: „, Głosimy Pana Jezusa Chrystusa”. Treść przepowiadania, red. H. Sławiński, Kraków 2017, s. 261-280.

I. Kosmana, op. cit. , s. 82.

Zob.: D. Żrałko, Biografia Fabiana Birkowskiego w świetle kazania pogrzebowego Adama Makowskiego i badań archiwalnych, „Pamiętnik Literacki”, 2005, z. 2, s. 215-227; M. Rowińska-Szczepaniak, Miejsce Fabiana Birkowskiego w dominikańskim ,łańcuchu pamięci”, w: F. Birkowski, Mowy akademickie i polemiczne. Orationes 
jego uczeń zwykle był oceniany przez badaczy homiletyki ${ }^{8} \mathrm{w}$ świetle swojego poprzednika na królewskiej ambonie. Tym razem również uwaga zwrócona zostanie na związek Birkowskiego z „ojcem nowożytnej hagiografii”. Nie będzie on jednak dotyczył oceny sztuki przepowiadania dominikanina, lecz dokonanej przez niego błędnej interpretacji tekstu źródłowego, który Skarga dołączył do Żywotu błogosławionego Jana Kantego. Każdemu z nich Szymon Starowolski poświęcił należne miejsce w dziele De claris oratoribus Sarmatiae. O Birkowskim napisał m.in.: ,znany jest jako mówca dzięki mowom drukowanym: i łacińskim, i polskim, które zwykł publicznie wygłaszać ku szczególnemu ukontentowaniu słuchających"9. Dzisiaj tę opinię trudno w pełni powtórzyć. Jeśli bowiem znany jest, to raczej wąskiemu gronu czytelników - badaczy i to głównie z dorobku powstałego w języku polskim. Dodać należy również, że w roli hagiografa rzadko stanowił obiekt naukowej refleksji. Nazwisko tego barokowego kaznodziei widnieje jednak w Słowniku hagiografów polskich, a więc umieszczony został w gronie osób, będących autorami, tłumaczami lub wydawcami pozycji z zakresu żywotopisarstwa świętych ${ }^{10}$. W niniejszym artykule analizie poddana zostanie mowa Academicus catholicus sive de b. Ioannis Cantii theologi, virtutibus catholicis, oratio, pochodząca z tomu Orationes ecclesiasticae, która dotąd nie ukazała się w języku polskim.

\section{Pod patronatem syna Akademii}

Fabian Birkowski już jako student, a następnie wykładowca krakowskiej Almae Matris uczestniczył w pielęgnowaniu kultu Jana z Kęt, także wychowanka i profesora tejże uczelni. Siedemnastowieczny mówca wawelskiej i mariackiej ambony akademickiego patrona nie tylko obrał za wzorzec swojego postępowania, ale i piórem podtrzymywał pamięć o średniowiecznym profesorze ${ }^{11}$. O tej szczególnej więzi między nimi wspomniał ks. Adam Makowski w mowie wygłoszonej na pogrzebie Birkowskiego. Zwrócił się wówczas do przedstawicieli społeczności uniwersyteckiej, podkreślając przywiązanie dominikanina do środowiska, w którym zdobył wykształcenie, pracował i dawał świadectwo chrześcijańskiego życia: ,znał się on do was i stał przy was za żywota, pisał i wysławiał was, akty publiczne obecnością swoją zdobił światłem przykładu młodzi waszej świecił, a ku bł. Kantemu wielce nabożny

academicae et polemicae, z języka łacińskiego tłum. B. Gaj, oprac. i komentarze B. Gaj, M. Rowińska-Szczepaniak, Warszawa 2016, s. 163-197.

8 Głównie dotyczy to badań prowadzonych w XIX wieku., np.: A. Szlagowski, Żywot, charakterystyka i dzieła ks. Fabiana Birkowskiego, w: Mowy pogrzebowe i przygodne ks. Fabiana Birkowskiego, cz.1, Warszawa 1901, s. 36-38; A. Jougan, Homilie polskie od czasów najdawniejszych po dobę obecną. Szkice bibliograficzne i krytyczne, Lwów 1902, s. 240-245.

9 S. Starowolski, De claris oratoribus Sarmatiae. O znakomitych mówcach Sarmacji, wyd. i tłum. E.J. Głębicka, Warszawa 2002, s. 65.

10 O kryteriach zaliczenia przez autorki Słownika danego pisarza do grona hagiografów zob. A. Witkowska, J. Nastalska, Staropolskie piśmiennictwo hagiograficzne, t. 1: Słownik hagiografów polskich, Lublin 2007, s. XIX.

11 Poza wskazanym tekstem napisał również Kazanie o ćwiczeniu młodzi przy pamięci b. Jana Kantego, akademika krakowskiego, które ukazało się w: F. Birkowski, Kazania obozowe o Bogarodzicy..., Kraków 1623, s. 71-86; idem, Kazania na niedziele i święta doroczne, Kraków 1628, s. 63-69. Zob.: M. Rowińska-Szczepaniak, Mistrz i uczniowie. O etosie „młodzi chrześcijańskiej” w świetle kazania Fabiana Birkowskiego, w: Na przełomie wieków... Studia i szkice ofiarowane Profesorowi Zdzisławowi Piaseckiemu w czterdziestolecie pracy naukowej, red. W. Hendzel, P. Obrączka, Opole 2003, s. 261-270. 
był”"2. Kaznodzieja, głosząc pochwałę zmarłego syna Akademii Krakowskiej - „naszej Matki", odwołał się do rozmowy, w której Birkowski porównał wszechnicę do religii ${ }^{13}$. Choć Makowski zaakceptował propozycję nowej formuły porównawczej, to jednak podkreślił rolę Akademii związaną z „,macierzyństwem” - by „,była Matką i dodawała dziatek Religiej"14. To, że potrafiła sprostać owemu zadaniu, a więc wypuszczała nie tylko dobrze wykształconych absolwentów, ale i świątobliwych mężów, odnotował kronikarz ks. Stefan Ranatowicz, wskazując m.in. na postać bohatera niniejszego opracowania: ,promieniowała światłem” - „błogosławionym Janem Kantym, Pisma Świętego doktorem, w swej Akademiej profesorem, teraz cudami sławnym, w kościele collegiackim świętej Anny odpoczywającym"15. O wychowankach krakowskiej uczelni, w tym Janie Kantym, pisał także Piotr Skarga: „Żył w doskonałych cnotach, światu i ciału umarły, samemu Panu Bogu chcąc się podobać, na którego się służbę wszytek i cale oddał; nic na świecie nie pragnął ani mieć chciał, w rzeczy niewidome i przyszłe serce wszytko odwróciwszy""16. Pielęgnowanie kultu Jana z Kęt, zanim doszło do oficjalnego uznania jego świętości przez Stolicę Apostolską ${ }^{17}$, przypominają krakowskie kalendarze, okolicznościowe kazania czy druki promocyjne (upamiętniające bakalaureat studentów Akademii Krakowskiej) z poetyckimi strofami wdzięczności skierowanymi do patrona uczelni ${ }^{18}$.

W swojej akademickiej oraz kapłańskiej posłudze Birkowski zachęcał do naśladowania cnót profesora oraz dawał dowody duchowej przyjaźni ze świętym. Przykładem jest choćby zwrot meus Cantius (Cantio meo, Cantii mei) stosowany w łacińskiej mowie jemu poświęconej: Academicus catholicus... ${ }^{19}$. Birkowski nie wszystkie mowy składające się na tom Orationes ecclesiasticae, a powstałe w okresie przed i po jego wstąpieniu do dominikanów, opatrzył informacjami: kiedy, gdzie, z jakiej okazji, przez kogo (niekiedy przez ucznia) były wygłoszone. Ta - upamiętniająca Jana z Kęt - jest ich pozbawiona, jedynie z samej treści

\footnotetext{
12 A. Makowski, Obraz wielebnego ojca Fabiana Birkowskiego z zakonu Dominika świętego doktora wystawiony na kazaniu pogrzebnym, Kraków 1636, s. 23.

13 Ibidem, s. 22. Dominikanin w jednej z łacińskich mów akademickich swój stosunek emocjonalny do uczelni wyraził także w zwrocie: „Matko, [...] nieskalany i wyjątkowy kwiecie, moja Akademio Krakowska” (F. Bircovius, Academica prima, sive de impedimentis bonarum litterarum, w: idem, Orationes ecclesiasticae, Cracoviae 1622, s. 480).

14 A. Makowski, op. cit., s. 22.

15 S. Ranatowicz, Jasna pochodnia życia apostolskiego..., Kraków 1660, k. A2.

16 P. Skarga, Żywot błogosławionego Jana Kantego, doktora Akademiej Krakowskiej, Kraków 1667, k. A3.

17 Beatyfikacja odbyła się 27 IX 1680 r., a kanonizacja 16 VII 1767 r. O przebiegu procesów oraz o życiu i twórczości Jana z Kęt zob.: M. Rechowicz, J. Swastek, Jan z Kęt, w: Nasi święci. Polski słownik hagiograficzny, red. A. Witkowska, Poznań 1999, s. 293-305; W. Gasidło, Ku czci świętego Jana z Kęt w sześćsetlecie jego urodzin 1390-1990, Kraków 1991, s. 84-93; R.M. Zawadzki, Św. Jan Kanty w świetle najnowszych badań, w: Święty Jan Kanty. W sześćsetna rocznicę urodzin 1390-1990, oprac. R.M. Zawadzki, Kraków 1991, s. 7-24; R.M. Zawadzki, Spuścizna rękopiśmienna świętego Jana Kantego, Kraków 1995.

18 Zob.: Z. Baran, Św. Jan Kanty w kulturze literackiej Polski przedrozbiorowej, w: Święty Jan Kanty. W sześćsetna rocznice urodzin..., op. cit., s. 103-114; R.M. Zawadzki, Staropolski konterfekt świętego Jana z Kęt, Kraków 2002, s. 185-265; E. Buszewicz, Fragmenty wielkich (księgo)zbiorów. Okolicznościowe publikacje Kazimierza Fortunata Albrychowicza zwiazane z promocjami na Uniwersytecie Krakowskim, w: Monastycyzm XV-XVIII wieku. Tradycja średniowieczna wobec wyznań nowożytnego humanizmu, red. M.T. Gronowski, P. Urbański, Warszawa 2016, s. 282-283.

19 Zob. M. Rowińska-Szczepaniak, Sidus Cracoviensis Academiae. Lacińska mowa Fabiana Birkowskiego pochwała cnót Jana z Kęt, w: Teksty - konteksty - interpretacje. W kręgu literatury, języka i kultury, red. E. Dąbrowska, K. Kossakowska-Jarosz, Opole 2007, s. 121-129.
} 
czytelnik dowiaduje się do przedstawicieli jakiego środowiska została skierowana - Viri Academici. Zakładając, że - jak wynika z dalszej części niniejszych rozważań - Birkowski, pisząc mowę, znał $\dot{Z} y$ wot krakowskiego profesora autorstwa Piotra Skargi, wydany po raz pierwszy w 1610 r., należałoby przyjąć, iż powstała ona po tej właśnie dacie.

\section{W szkole ,sztuki zapominania”}

Fabian Birkowski, wykorzystując biblijny motyw „,pióra pisarza prędko piszącego”20, jednocześnie ujawnia swoją zgodę na bycie narzędziem w rękach Boga: „Niech dziś język mój będzie trzciną Pisarza lotnie piszącego, gdy wypowiada pochwały Jana Kantego, katolickiego akademika. Nauczaj Ty, który jesteś najwyższą chwałą i w świętym mieszkasz, chwało Izraela, Boże Najlepszy, Największy"21. Ukazana w mowie Academicus catholicus... sytuacja komunikacyjna ma złożony wymiar. Dzieje się tak poprzez zastosowanie różnych poziomów relacji nadawczo-odbiorczych ${ }^{22}$, w których uczestniczą: nadawca (pośrednik), odbiorca, bohater, przy zastosowaniu zmienności ról. Autora, będącego pośrednikiem w przekazywaniu treści - Bożym ,piórem”, można poznać bliżej, np.: gdy konfrontuje rozważania z rzymskim poetą Wergiliuszem - ,ja zaś mógłbym powiedzieć, nieco zmieniając” (Ac., 318), odwołując się do autorytetu starożytnych mędrców (Izokratesa, Cycerona) - ,ja przypominam” (Ac., 317), w dialogu z samym sobą - ,upominam się” (Ac., 321) czy podczas ujawniania osobistego stosunku do bohatera - „mój Kanty” (Ac., 315, 318), który jest także adresatem wypowiedzi. Birkowski w sposób bezpośredni zwraca się do niego: „Janie Kanty, Mężu najwybitniejszy”, „Twoja nauka”, „Twoja cnota”, a więc staje się on współuczestnikiem spotkania, podobnie jak mężowie akademiccy. Oni z kolei nie są jedynie milczącymi odbiorcami, świadkami zdarzenia, lecz również przejmują funkcję rozmówcy. Orator, domyślając się, iż stawiane wymagania w kontekście proponowanego wzorca, mogą być przez słuchających odebrane jako zbyt trudne do realizacji, udziela im głosu. Po przedstawieniu się: „my jesteśmy akademikami" (nos Academici sumus), opowiadają o stanie swojego niepokoju wywołanego codziennymi problemami, które utrudniają im pozytywne relacje z drugim człowiekiem: „miotają nami różne opinie i kłopoty, desperacje. Przychodzi tysiąc okazji, sytuacji, które czynią z nas zabieganych, obciążonych, melancholików, zagniewanych, a inni muszą to znosić i albo wybaczyć, albo zignorować" (Ac., 318). Mówca w odpowiedzi (identyfikując się z adresatami) wyjaśnia: „nie była dla nas natura taką macochą, abyśmy niczego nie potrafili zmienić, dokonać czy też oduczyć się przyzwyczajeń, których się wstydzimy. Czy jesteśmy lwami albo tygrysami, o których Seneka pisał, że tylko rozsiewają dzikość?” (Ac., 318). W uzasadnieniu autor ma na uwadze nie tylko wskazanego odbiorcę, lecz każdego czytelnika (słuchacza), przypominając: „my jesteśmy ludźmi” (nos homines sumus), a to zobowiązuje do określonej postawy. Ludźmi, dodaje, których „natura stworzyła bezbronnymi i nagimi, abyśmy byli oddani życiodajnemu pokojowi, a dziki gniew pozostawili leśnym

\footnotetext{
20 Ps 44(45),2 (Biblia J. Wujka, dalej - BW); ,rylca biegłego pisarza” - Ps 45 (44),2 (Biblia Tysiąclecia, dalej BT).

${ }^{21}$ F. Bircovius, Academicus catholicus, sive de b. Ioannis Cantii theologi, virtutibus catholicis, oratio, w: idem, Orationes..., op. cit., s. 312 (dalej: Ac., s.).

22 Zob. A. Okopień-Sławińska, Relacje osobowe w literackiej komunikacji, w: Problemy socjologii literatury, red. J. Sławiński, Warszawa 1971, s. 109-125.
} 
zwierzętom" (Ac., 319) $)^{23}$. Dalej, to samo zdanie-twierdzenie, aby wzmocnić perswazyjny charakter narracji, kieruje do pojedynczego adresata: „Ty jesteś człowiekiem” (Tu homo es), który „ujarzmia dzikie zwierzęta”. Stąd w sytuacjach trudnych zaleca wykorzystać „berło rozumu”, a treść sentencji, nawiązującej do słów Seneki, uczynić mottem swojego działania: „Nie poddam się, do większych rzeczy zostałem zrodzony, niż być niewolnikiem swego ciała” (Ac., 319) ${ }^{24}$. Autor dopowiada - jesteś „,bogiem ziemskim”, by podkreślić owo wyróżnienie człowieka przez Stwórcę, o czym mowa w Księdze Rodzaju: „Bóg stworzył człowieka, na podobieństwo Boga stworzył go ${ }^{25}$; stworzył mężczyznę i niewiastę, pobłogosławił ich i dał im nazwę «ludzie», wtedy gdy ich stworzył"26. Powierzył im również konkretne zadania: „Bądźcie płodni i rozmnażajcie się, abyście zaludnili ziemię i uczynili ją sobie poddaną; abyście panowali nad rybami morskimi, nad ptactwem powietrznym i nad wszystkimi zwierzętami pełzającymi po ziemi"27. Co więcej, Birkowski podkreśla, że „Duch ludzki chrześcijański i katolicki nie tylko przewyższa dzikie zwierzęta, głupców, ale i anioły" (Ac., 320), nawiązując w swej argumentacji do retorycznego pytania, jakie św. Paweł skierował do mieszkańców Koryntu: Nescitis, quoniam et Angelos iudicabimus?28. Podnosząc kwestię godności człowieka, Birkowski odwołuje się także do wezwania Chrystusa, by miłować nieprzyjaciół i modlić się za nich, bowiem dopiero wtedy - jak podkreśla kaznodzieja i daje za przykład postawę pierwszego męczennika Szczepana ${ }^{29}$ - spełnione zostają warunki pozwalające doświadczyć „życiodajnego pokoju”. „Przyobleczony” w taką miłość, będącą - według słów św. Pawła - „więzią doskonałości”"30, był właśnie św. Jan Kanty. Ojciec Fabian zaznacza, że zasad postępowania, w tym umiejętności przebaczenia, uczył

\footnotetext{
23 O aspekcie etycznym natury ludzkiej mowa jest w dziele Cycerona: ,dusza mądrego człowieka nie wpada we wszelką chorobę i namiętność. Dzikość i okrucieństwo dalekie są od niej. Ludzkie tylko uczucia mają moc nad nią, jako to litość, bojaźń, zmartwienie" (M.T. Cyceron, Rozmowy tuskulańskie, w: Pisma filozoficzne, cz.1, thum. E. Rykaczewski, Poznań 1874, s. 416).

24 Por. L.A. Seneca, Listy moralne do Lucyliusza, tłum. W. Kornatowski, wstęp i przypisy K. Leśniak, Warszawa 1961, s. 229. Należy przypomnieć, że słowa: „Ad maiora natus sum” stanowiły życiową dewizę św. Stanisława Kostki, cieszącego się - obok św. Jana z Kęt - dużą popularnością w XVII w.; zob. Z. Hadrych, Kazania jako źródto informacji o świętych i epoce, „Archiwa, Biblioteki i Muzea Kościelne”, 67/1997, s. 383-386.

25 Birkowski dzieło Boga-Stwórcy (w innym tekście) zestawia z dziełem malarza: „Niechaj malarz, który maluje wszytko od ręki jakoby linie na ściany pędzlem rzucał, weźmie potem konterfekt i postawi przed oczy, i usiędzie, aby malował, spodziewamy się czegoś wielkiego na ten czas. Tak Bóg właśnie uczynił: przez sześć dni pomalował śliczne kreatury [...], a gdy do człowieka przyszedł, zaraz go z konterfetu maluje, którego? nie innego jedno z siebie samego: «Na obraz nasz»” (F. Birkowski, Na II. Niedziele Adwentowa, kazanie pierwsze, w: idem, Kazania na niedziele..., op. cit., s. 15).

26 Rdz 5,1-2, BT (por. Rdz 1,26). Birkowski, obok przyrodzonego aspektu godności człowieka, również zwraca uwagę na nadprzyrodzony. Dignitas hominis jako temat podejmowany przez Ojców Kościoła, zyskał duże zainteresowanie w okresie renesansu, czego wyrazem ówczesne traktaty. Zob. J. Czerkawski, Humanizm i scholastyka. Studia z dziejów kultury filozoficznej w Polsce w XVI i XVII wieku, Lublin 1992, s. 33-45.

27 Rdz 1,28, BT.

28 „Nie wiecie, że i aniołów będziemy sądzić?” Chodzi o tzn. aniołów upadłych. Zob.1 Kor 6,3, BT; por.: 2P 2,4; Jud 6 i 1 Kor 6,2, BW.

29 Zob. Mt 5,43-44; Dz 7,58-60, BT. F. Birkowski o św. Szczepanie pisze: „wśród padających kamieni szukał róż i lilii, i modlił się za swoich nieprzyjaciół, aby to kamienowanie nie sprowadziło na nich potępienia" (Ac., 315).

30 Zob. Kol 3,14-15, BT.
} 
się nie z „tablic rzymskich”"31 czy aktów amnestii (darowania kary - „zapomnienia”32), lecz przyjmując nakaz z nieba, bezpośrednio od Chrystusa. Autor wydobywa podwójny sposób realizacji tego zadania przez Kantego: w ramach indywidualnej pracy nad sobą - „zanim przystąpił do ołtarza wyrzucał z serca całą gorycz, aby z czystym sercem i czystymi rękoma sprawować Najświętszą Ofiarę” - oraz w roli duszpasterza nauczającego wiernych - „Przed ołtarzem zachęcał braci, według wskazówki Pańskiej, aby wybaczali sobie, jeśli ktoś ma coś przeciw komuś” (Ac., 315, 316). Birkowski trudną sztukę przebaczania łączy z nakazem „niepamięci”, nawiązując do wypowiedzi Temistoklesa, który na propozycję uczenia się sztuki zapamiętywania odpowiedział: „Wolałbym sztukę zapominania. Bo pamiętam nawet to, czego nie chcę pamiętać, a nie mogę zapomnieć tego, co zapomnieć chciałbym"33. O akademickim patronie dominikanin stwierdza: „Znał godność swej natury Kanty i nie tylko nie mąciły jego spokoju zniewagi, jakimi mógł go obrzucić zły człowiek, ale nawet szatan, który straszył go jako wąż i pijawka w czasie Mszy św.” (Ac., 320) ${ }^{34}$. Na nic jednak zdały się rozmaite zabiegi złego ducha, np. wzniecanie sporów miedzy wykładowcami, próby wzbudzenia nienawiści i zazdrości w sercu, aby oderwać Kantego od miłości do Boga. W tym zmaganiu bohatera Birkowski odnajduje podobieństwo do świadectwa Hioba. Był to - wyjaśnia - „człowiek prosty i prawy, i stroniący od złego” (Ac., 313), którego nieczysty duch na próżno usiłował pozbawić niewinności.

\section{W dialogu z niebem, aby wyżej i dalej}

Fabian Birkowski, wskazując na cechy postępowania mistrza Jana, uwzględnia fakt jego przynależności do określonych wspólnot. Czyni to stwierdzeniem - „nasz” święty, podkreślając w ten sposób nie tylko osobisty stosunek do postaci („mój” Kanty), lecz także wszystkich słuchaczy (czytelników). Zastosowana forma zaimka dzierżawczego przypomina, że bohater związany był z krakowskim środowiskiem naukowym, do którego mówca przemawia i z nim się utożsamia, jak i o tym, że był Polakiem oraz należał do wspólnoty Kościoła. Poprzez swoje pochodzenie, miejsce wykształcenia i pracy stał się znakiem rozpoznawczym konkretnego kraju, miasta, zbiorowości, a życiem poświadczał o wyznawanej wierze katolickiej.

Warto zauważyć, że gdy kaznodzieja porusza problem heroiczności cnót Kantego w kontekście duchowej walki, w celu jej zobrazowania, posługuje się symbolem muru. Oznacza on stałość bohatera w wierze i wewnętrzną siłę, by jej bronić. O Kantym pisze, że „stał jak

\footnotetext{
31 W innej mowie łacińskiej (Academica secunda, sive de virtute acquirenda) Birkowski również wykorzystuje przykład ustawy dwunastu tablic. Przez odwołanie się do opinii rzymskiego polityka M.L. Krassusa, który nazywa je „bibliotekami wszystkich filozofów”, podejmuje kwestię dotyczącą źródła sztuk i dziedzin wiedzy (F. Bircovius, Orationes..., op. cit., s. 487). O tym pomniku prawa rzymskiego pisze M. Zabłocka, Pierwsza palingenezja ustawy XII tablic, „Prawo Kanoniczne: kwartalnik prawno-historyczny”, 1993, nr 3-4, s. 149-155.

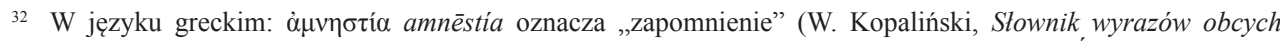
i zwrotów obcojęzycznych, Warszawa 1998). Na temat amnestii w prawie rzymskim zob.: P. Święcicka, Proces Jezusa w świetle prawa rzymskiego. Studium prawno-historyczne, Warszawa 2012, s. 230-231.

33 M.T. Cyceron, De finibus bonorum et malorum [O najwyższym dobru i złu], w: idem, Pisma filozoficzne, t. 3, tłum. W. Kornatowski, komentarz K. Leśniak, Warszawa 1961, s. 272.

34 Tu Birkowski nawiązuje do wydarzenia opisywanego w żywotach św. Jana z Kęt. Mocą Bożą rozprawił się z „,nieprzyjacielem dusznym”, który, ukrywając się pod postacią jaskółki, przeszkadzał w Mszy św., sprawowanej w kościele św. Anny w Krakowie i ostatecznie jako wąż opuścił święte miejsce. Por.: Świadectwo Macieja Miechowity, historyka polskiego, o tym B. Janie Kantjusie, słowo od słowa, w: P. Skarga, Żywot błogosławionego Jana Kantego..., op. cit., k. Bv.
} 
niewzruszony mur przeciwko tym pociskom miotanym z wojennych machin szatańskich [...], podczas gdy atakowano go w coraz silniejszych pojedynkach i jakby potokami złorzeczeń [...] najniewinniejszy mąż powstrzymywał się i milczał, gdy grzesznik występował przeciwko niemu" (Ac., 313). Wprowadzał w życie zasady ujęte w formie sentencji: Conturbare cave, non est placare suave. / Infamare cave, nam revocare grave (Ac., 313). Stawiane sobie wymagania także ujmował słowami psalmisty: „Będę strzegł dróg moich, abym nie zgrzeszył językiem moim. Założyłem straż ustom moim" "35. Dominikanin, mówiąc o podejmowanej walce i zwycięstwach bohatera nad samym sobą, gdy przykładowo ćwiczył się w zakresie sztuki przebaczania, doświadczając przykrości, oraz o pouczaniu skrzywdzonych niesprawiedliwymi sądami, przypomina o towarzyszącym mu zawołaniu - Ut supra: „Powiedzeniem mojego Kantego i własnoręczną inskrypcją było: «Aby wyżej»” (Ac., 315). Birkowski podaje, że tę właśnie dewizę Kanty zapisał na ścianie swojego mieszkania i wskazuje na źródło biograficznej informacji, jaki stanowić miała dla niego Chronica Polonorum Macieja z Miechowa ${ }^{36}$. Tu jednak pojawia się problem. W rozdziale 69 księgi 4 tego dzieła owszem znajdują się wiadomości o św. Kantym, w tym o sentencjach, których treść utrwalił w formie pisemnej, nie ma natomiast mowy o wyrażeniu - Ut supra. Wspomniane sentencje w niniejszych rozważaniach były już przywołane, bowiem kaznodzieja wykorzystał je w analizowanej mowie. W tłumaczeniu Piotra Skargi treść ich przedstawia się następująco: „Strzeż się kogo zafrasować, bo nie smaczno przeprawować. / Sławy nie ruszaj bliźniego, bo odwołać coś ciężkiego" ${ }^{37}$. Zdaniem Romana Zawadzkiego, badacza życia i twórczości mistrza z Kęt, „Maciej zapewne widział te wiersze na własne oczy, skoro zaraz potem dodał uwagę, iż ten napis strzeżono przed zniszczeniem aż do czasu, kiedy w Kolegium podjęto prace remontowe i ścianę z tym napisem wyburzono" 38 . Nasuwa się wniosek, że Birkowski przy pisaniu mowy nie korzystał bezpośrednio z Kroniki Miechowity. Dominikanin znał Żywot błogosławionego Jana Kantego autorstwa Piotra Skargi, do którego jezuita dołączył biogram zatytułowany Świadectwo Macieja Miechowity..., stanowiący fragment dzieła polskiego historyka. Tłumacząc tekst na język polski, w miejscu gdzie w oryginale po słowie „scripsit” pojawiają się sentencje Conturbare cave... Skarga napisał - ut supra. Zdanie w całości brzmiało: „Gdy mu na onych schadzkach kto łajał i słowa na jego krzywdę mówił, on na ścianie mieszkania swego węglem pisał: ut supra" ${ }^{\text {39 }}$. Birkowski zatem wyrażenie: $U t$ supra (w znaczeniu „Aby wyżej”) przyjął za życiową dewizę świętego. Skarga natomiast, nie chcąc po raz kolejny przytaczać tej samej treści, a więc owych sentencji, wprowadził wyrażenie: ut supra (w znaczeniu ,jak wyżej”), mające pełnić funkcję analogiczną do współczesnego ,przypisu w tekście”. Trzy strony wcześniej (w Żywocie błogosławionego Jana Kantego) sentencje te zacytował w wersji łacińskiej i polskiej, komentując: „te słowa i drugim na przykład na ścianie swojej pisał"40. Błędna interpretacja wskazanego fragmentu znalazła kontynuatorów, trudno jednak powiedzieć, na ile pod wpływem lektury mowy dominikanina. Osiemnastowieczne przykłady odwołania się w okolicznościowych

\footnotetext{
35 Ps 38(39),2, BW.

36 Zob. M. Miechowita, Chronica Polonorum, Kraków 1521, s. 338.

37 P. Skarga, Żywot błogosławionego Jana Kantego..., op. cit., k. A3v.

38 R.M. Zawadzki, Staropolski konterfekt..., op. cit., s. 80.

39 P. Skarga, Żywot błogosławionego Jana Kantego..., op. cit., k. A4v-B.

40 Ibidem, k. A3v.
} 
wystąpieniach ${ }^{41}$ do wyrażenia Ut supra jako dewizy przybliżającej duchowość Kantego, to jeszcze nie wszystko. Podczas krakowskich uroczystości dla uczczenia kanonizacji świętego, zorganizowanych w 1775 r., wśród licznych elementów składających się na dekorację miasta znalazły się medaliony, przedstawiające historię jego życia i cudów. Na siódmym (z osiemnastu) widniała postać Kantego ze wzrokiem skierowanym w kierunku Opatrzności, z którego ust wydobywały się słowa: Ut supra. Obok umieszczono naśmiewającą się i odstraszającą swym wyglądem kobietę z wężami na głowie. Do jej rąk włożono rekwizyty: strzały oraz maskę z napisem: „Vivitur UT SUPRA, vivit convicia spernit, / Atque nihil Sanctos tangere probra docet. / Gdy Bóg świadkiem sumienia, niech sobie świat szydzi, / Jan mówi: cnoty żadna potwarz nie ohydzi" ${ }^{42}$.

Wyjaśnienie dotyczące mylnego odczytania tekstu przez Birkowskiego nie przekreśla celowości kontynuowania pracy nad mową dominikanina, a wręcz przeciwnie. Warto przyjrzeć się, jak autor na podstawie posiadanej wiedzy prowadzi dalszą narrację w kierunku zarysowania kondycji duchowej Kantego. Obecna w pisarstwie Birkowskiego zasada, polegająca na eksponowaniu określonych cech wybranych postaci i realizowanych przez nie zadań za pomocą konfrontacji postaw i myśli, zostaje również wykorzystana w omawianym przypadku. Mówca akceptuje powiedzenie Karola V: Plus ultra (utworzone w opozycji do ostrzeżenia Herkulesa: Nec plus ultra ${ }^{43}$ ) i wyraża swój sprzeciw wobec głosu - jak nazywa „godnego” szkoły Epikura: Quae supra nos, nihil ad nos ${ }^{44}$, uważając, że właśnie to, co ponad nami, nas dotyczy. Stąd formułuje następujące przesłanie: „musimy stale prowadzić rozmowę z niebem, jeśli chcemy być uznawani za chrześcijan” (Ac., 315). Uznając za życiowe motto Kantego - „Aby wyżej”, zestawia je z dewizą króla hiszpańskiego - „Więcej i dalej”. W obu przypadkach chodzi o aktywność związaną z podejmowaniem wyzwań oraz pokonywaniem granic, które hamują odkrywanie dobra i prawdy. Birkowski tym samym wskazuje na dwa źródła poznania wzajemnie się uzupełniające: w pierwszym przypadku jest nim wiara, w drugim - rozum. Myśl tę rozwija w jednej z mów akademickich, także ogłoszonych w zbiorze Orationes ecclesiasticae, zachęcając wychowanków do zdobywania

\footnotetext{
41 Zob.: F.B. Mąsiorski, Vita activa et contemplativa relata ad Cantianum dictum factumque „,Ut supra”, brevi proloquio deducta..., Cracoviae 1771; A. Niemirycz, Ut supra, w: J.A. Putanowicz, Życie, cuda i dzieje kanonizacji S. Jana Kantego..., Kraków 1780, k. Eee-Fffv; R.M. Zawadzki, Staropolski konterfekt..., op. cit., s. 226.

42 Dziennik oktawy na pamiątkę kanonizacji S. Jana Kantego..., w: J.A. Putanowicz, op. cit., k. R2v.

43 Napisy „Ani kroku dalej” na kolumnach Herkulesa po obu stronach Cieśniny Gibraltarskiej informowały podróżnych o końcu zamieszkałej części świata. Zob.: R. Graves, Mity greckie, tłum. H. Krzeczkowski, wstęp A. Krawczuk, Warszawa 1974, s. 460-461; M. Koźluk, Bivium virtutis et vitii - èthos Herkulesa w szesnastoi siedemnastowiecznej ars emblematica, w: Prace Herkulesa-człowiek wobec wyzwań, prób i przeciwności, red. M. Cieśla-Korytowska, O. Płaszczewska, Kraków 2012, s. 59-74. Słupy Herkulesa ze wskazanym mottem znalazły swoje miejsce w emblemacie Karola V. Zagadnienie omawia D. Hernández de la Fuente, Herkules w Hiszpanii: szkic o mitologii $i$ symbolizmie, w: Prace Herkulesa..., op. cit., s. 75-86. Herkulesowe słowa w zmienionej wersji zastosował Mikołaj Szomowski w kazaniu o męce i śmierci Chrystusa: „te ich zapisy Pan i Zbawiciel nasz Jezus pomazał, a sam krwią swoją napisał: Plus ultra. Dalej jeszcze, dalej” (M. Szomowski, Raj niebieski na ziemi, potopem złości i okrucieństwa żydowskiego zniesiony abo kazanie na Wielki Piatek miane..., Warszawa 1655, s. 35). Zob. M. Kuran, Barokowy kaznodzieja czyta rzymskich pisarzy (na przykładzie wielkopiatkowego kazania Mikołaja Szomowskiego „, Raj niebieski na ziemi, potopem złości i okrucieństwa żydowskiego zniesiony...”), „Czytanie Literatury. Łódzkie Studia Literaturoznawcze", 2012, nr 1, s. 199-202.

44 „To, co ponad nami, nie tyczy się nas” (Ac.,315). Por. D. Erasmus, Adagia, Leiden 1703; Erazm z Rotterdamu, Adagia, wybór, tłum. i oprac. M. Cytowska, Warszawa 1973; A. Alciato, Emblematum liber, Augsburg 1531; A. Alciatus, Emblematum libellus. Książeczka emblematów, tłum. A. Dawidziuk, B. Dziadkiewicz, E. Kustroń-Zaniewska, wstęp i oprac. R. Krzywy, Warszawa 2002.
} 
wiedzy bez wyznaczania granic oraz do kierowania się dewizą Karola V Plus ultra . Mówiąc o charakterze kształcenia humanistycznego, ostrzega przed samozadowoleniem, opieszałością, przyjemnością i zaleca, by podczas studiów korzystać z określonych wzorców: „Sztukę uczenia się odnoście nie do was samych, ale do wielu szczególnie wybitnych ludzi. Z nich czerpcie to, co jest użyteczne i konieczne. Tak właśnie umysł musi dokonywać szlachetnego postępu w naukach humanistycznych: «dalej i dalej»»"45.

Birkowski, stawiając w imieniu swoich słuchaczy pytanie, jaką wiedzą kierował się Kanty, udziela na nie następującej odpowiedzi: „Nie była ona inna niż katolicka. Najwyższą spośród dziedzin wiedzy - teologią, której nie chciał czerpać z dziurawych cystern, które nie mogą utrzymać wody, czyli z potoków husyckich lub waldenskich, lecz z samego rzymskiego źródła" $\left(\right.$ Ac., 320 ${ }^{46}$. W tym miejscu autor nawiązuje do słów łacińskiego apologety afrykańskiego z II wieku Tertuliana, pisząc: ,Szczęśliwe jest położenie Kościoła, który całą wiedzę czerpie od Piotra i Pawła, którzy za nią krew swą przelali’" ${ }^{47}$. Zwracając się do odbiorcy, przypomina o pielgrzymowaniu świętego profesora do tego źródła wiedzy: „Mężowie akademiccy, macie oto syntezę szaty (togi) bł. Jana Kantego, a jest to szata rzymskiej teologii, bo był on wielkim czcicielem Siedziby Rzymskiej i często odwiedzał tę ziemię, której dotykały stopy apostołów i gdzie płynęła krew męczenników [...] był doktorem teologii, wargi jego strzegły wiedzy, którą przyjmował wprost z ust Piotra, który w Rzymie przemawia przez swego Namiestnika" (Ac., 322) ${ }^{48}$. Jan Kanty postawą wierności wobec nauki Kościoła potwierdził, że słowa Apostoła Narodów skierowane do Rzymian o ich wierze opowiadanej po całym świecie zyskały swą trwałość nie tylko w przestrzeni, ale i w czasie. Birkowski w kontekście rozważań o pielgrzymowaniu mistrza Jana odwołuje się również do listu św. Pawła do Galatów ${ }^{49}$, a konkretnie do fragmentów przypominających o podróżach Apostoła. Dominikanin dostrzega w podjęciu przez świętego wędrówek do miejsc kultu (Jerozolimy, Rzymu) nie tylko potrzebę pokuty, ale także konfrontacji myśli i umocnienia w wierze ${ }^{50}$. Mówca zauważa, iż

\footnotetext{
45 F. Birkowski, Pierwsza mowa akademicka albo o przeszkodach $w$ dobrym ksztatceniu humanistycznym, w: idem, Mowy akademickie i polemiczne..., op. cit., s. 49-50.

46 Birkowski, kontynuując wątek polemiki religijnej, odwołuje się do poglądów: Jana Husa, Hieronima z Pragi, Jana Wiklifa (Wiklefa), Marcina Lutra. Pod adresem Akademii Krakowskiej kieruje następujące słowa pochwały: „Ty jedna na północy byłaś wierna nauce Piotrowej, a jeśli widziałaś coś złego, natychmiast wyrzucałaś” $(A c$., 321$)$.

47 F. Birkowski: „Statu felix Ecclesia, cui totam doctrinam Petrus et Paulus cum sanguine suo profuderunt” ( $A c$., 320). Por. Tertulian, De praescriptione haereticorum (XXXVI, 3): „Ista quam felix ecclesia cui totam doctrinam apostoli cum sanguine suo profuderunt " [,Jak szczęśliwy ten Kościół. Jemu to Apostołowie całą naukę razem z krwią swoją przelali"] (K.S.F. Tertulian, Preskrypcja przeciw heretykom, thum. E. Stanula, w: idem, Wybór pism, wstęp E. Stanula, oprac. W. Myszor, E. Stanula, Warszawa 1970, s. 71).

48 Birkowski posługuje się symbolem szaty (togi profesorskiej), bowiem w środowisku uniwersyteckim Krakowa istniał pewien zwyczaj, o którym można przeczytać w bulli kanonizacyjnej Ecclesiam suam papieża Klemensa XIII: „purpurową szatę Kantego, zwaną rewerendą, troskliwie przechowywaną, zwykł przywdziewać każdy nowo obrany dziekan Wydziału Filozoficznego, oświadczając przy tym, że wraz z tą szatą przybiera na się zarówno obyczaje, jak i cnotę tego wielkiego nauczyciela" (Clementis Divina Providentia Papae XIII Litterae decretales super canonizatione beati Ioannis Cantii presbyteri saecularis [promulgatae 16 VII 1767], wstęp W. Gasidło, thum. R.M. Zawadzki, Kraków 2004, s. 57).

49 Por. Rz 1,8 i Ga 1,$18 ; 2,2$.

50 Skarga pisze: „Polacy, którzy w Rzymie przemieszkiwali, dziwując się jego częstej do Rzymu przechadzce, pytali go dla czego się tak trudził [...], on im odpowiedział: «To mój czyściec, w którym moje grzechy obmywam i stąd biorę do dobrego żywota chrześcijańskiego ochotę»" (P. Skarga, Żywot błogosławionego Jana Kantego..., op. cit., k. A2-A3). Por. Świadectwo Macieja Miechowity..., op. cit., k. A6. O braku podstaw do przyjmowania prawdziwości przekazów o podróżach Mistrza Jana zob. R.M. Zawadzki, Spuścizna rękopiśmienna..., op. cit., s. $70-73$.
} 
podobna potrzeba nadal towarzyszy przedstawicielom różnych narodów, licznie pielgrzymującym do Wiecznego Miasta, których zestawia z osobami przybywającymi niegdyś do stolicy Imperium Rzymskiego, by wziąć udział w igrzyskach. Okazję dla porównania celów przyświecających podróżującym do starego i nowego Rzymu ${ }^{51}$ oraz wskazania miejsc ich pochodzenia stanowi dla Birkowskiego cytat zaczerpnięty z jednego z epigramów Marcjalisa. Gdy poeta przedstawia w nim przybywających cudzoziemców - kaznodzieja dopowiada, iż obecnie są wśród nich także Chińczycy, Japończycy, Amerykanie. Z kolei, gdy kończy tekst słowami uznania pod adresem cesarza: „Choć wiele brzmi języków, jednym się stają, kiedy / ojczyzny ojcem wszyscy prawdziwym ciebie zwą" 52 - Birkowski głosi pochwałę papiestwa, które „nigdy nie ulegnie herezji” (Ac., 323).

Zasygnalizowany we wstępie niniejszego opracowania postulat współczesnych badaczy zajmujących się hagiografią ponownego sięgnięcia do źródeł w celu ukazania autentyczności postaci świętych, będących ciągle aktualnymi wzorcami do naśladowania, stanowił asumpt do tego, by powrócić do świadectw świętości i kultu Jana z Kęt. W przeszłości, kreśląc sylwetki świętych, nie przykładano dostatecznej wagi do źródeł. Dla autorów licznych żywotów czy kazań istotne było bowiem nie tyle ścisłe trzymanie się faktów historycznych, co raczej ukazanie wzorca chrześcijańskiego życia, niejednokrotnie jednak zbyt odległego od realiów. Trudno się więc dziwić, że - jak twierdzi Roman Zawadzki - powstające w XVIII i XIX w. żywoty mistrza Jana wykorzystywały treści biograficzne nie zawsze w sposób rzetelny i tym samym nie wzbogacały wiedzy czytelników o nowe elementy ${ }^{53}$. Podobną uwagę odnieść można do wielu tekstów powstałych w wieku XVII. Także dla Fabiana Birkowskiego, kierującego się założeniami charakterystycznymi dla twórczości parenetycznej, dokładne ustalanie faktów w oparciu o dostępny materiał źródłowy było rzeczą wtórną. Takie podejście wyjaśnia, iż przywołując w swojej mowie Academicus catholicus... Kronike Miechowity, nie korzystał z tekstu oryginalnego, lecz bazował jedynie na tłumaczeniu Skargi. Efektem tego było popełnienie dość istotnego błędu interpretacyjnego, który skutkował przypisaniem świętemu słów niepochodzących w rzeczywistości od niego. Pomyłki tej dopuścili się również inni propagatorzy kultu patrona krakowskiej Almae Matris. Trudno jednak stwierdzić, czy była ona wynikiem lektury oracji Birkowskiego, czy też wytworem ich własnej inwencji. Nie ulega natomiast wątpliwości, iż słowa te pozostawiły swój ślad w dziejach kultu świętego, nie tylko jako motyw wykorzystywany w twórczości oratorskiej, ale również w sztuce wizualnej, a konkretnie w dekoracji przygotowanej z okazji obchodów zorganizowanych, by

\footnotetext{
51 Zob. A. Wargocki, O Rzymie pogańskim i chrześcijańskim ksiag dwoje, wyd. J. Sokolski, red. J. Kroczak, Warszawa 2011, s. 135.

52 Marcjalis, Księga widowisk, tłum. K. Różycka-Tomaszuk, wstęp i komentarze A. Klęczar, M. Zagórski, współpraca B. Burliga, Wrocław 2015, s. 80. W starożytnym Rzymie honorowy tytuł pater patriae otrzymywali zasłużeni obywatele, od 2 r. p.n.e. przysługiwał wszystkim cesarzom (zob. wyjaśnienie we wskazanym wydaniu Księgi widowisk, op. cit., s. 81). Birkowski w swoich tekstach dawał liczne dowody znajomości literatury starożytnej i twórczego jej wykorzystania. Przypomniał o tym A. Makowski w kazaniu na pogrzebie mówcy: „A któż był w te uczone fraszki pogańskie i poetyckie nad Ojca Fabiana bogatszy. Czytajcie jego oracje łacińskie, tam obaczycie, że i mitologów doszedł, i Likostenesom wyrównał, jako i św. Tomasz, Arsenius, i nasz Borgiasz, i inszy" (A. Makowski, op. cit. , s. 15).

53 R.M. Zawadzki, Spuścizna rękopiśmienna..., op. cit., s. 46.
} 
uczcić wyniesienie go na ołtarze. Roman Zawadzki, nie znajdując w źródłach potwierdzenia informacji o posługiwaniu się przez Kantego dewizą Ut supra, poprzestał jedynie na określeniu jej mianem „rzekomej” ${ }^{4}$. W dotychczasowym stanie badań nie wyjaśniono jednak, jak doszło do tego, iż słowa te uznane zostały za życiowe motto mistrza Jana. Stąd też problem ten podjęto w niniejszym opracowaniu. W wyniku popełnionego przez Birkowskiego błędu, wyrażenie to stało się jednym z elementów naszkicowanej przez dominikanina sylwetki świętego. I choć, ujmując zagadnienie historycznie, należy stwierdzić, iż słowa Ut supra nie były w istocie dewizą średniowiecznego profesora, to jednak nie można uznać, że nie nadawały się one do zobrazowania jego drogi do świętości.

Birkowski, kreśląc duchowy wizerunek Jana z Kęt, ukazał człowieka „przyobleczonego” w miłość Bożą, konsekwentnie odpowiadającego na wezwanie Chrystusa do tego, by kochać nieprzyjaciół. Postawa taka była możliwa dzięki nieustannemu ćwiczeniu się w trudnej sztuce „zapominania” prowadzącego do przebaczenia. Przyjmując ją, Kanty wyrażał swoją nadprzyrodzoną godność, będącą owocem stworzenia na obraz i podobieństwo Boga. Istotną rolę dla ukazania wewnętrznej postawy bohatera stanowiło porównanie go do muru będącego zaporą przeciwko mocom ciemności. Kanty przedstawiony został jako homo militans, toczący nieustanną walkę z ,szatanem, światem i ciałem”. Stosowanym przez niego narzędziem, umożliwiającym odnoszenie zwycięstwa, było milczenie, do którego zachęcały sentencje, jakie zapisał na ścianie swojego mieszkania. Ważny element duchowości mistrza Jana stanowiła również wierność katolickiej doktrynie, nauczanej przez niego jako profesora teologii. Kluczowa dla przedstawienia duchowej sylwetki Kantego stała się wreszcie wspomniana dewiza Ut supra, którą Birkowski zestawił z przyświecającą Karolowi V zasadą Plus ultra. Obie reguły uzupełniały się, podobnie jak dwa źródła poznania, a więc wiara i rozum. Wyrażały one „święte pragnienie”, o którym pisał włoski humanista Giovanni Pico della Mirandola, „by nie zadowalać się rzeczami miernymi, ale pożądać najwyższych i osiągać je, natężając wszystkie siły, ponieważ możemy tego dokonać, jeśli chcemy"55.

\section{Bibliografia}

Alciato A., Emblematum liber, Augsburg 1531.

Alciatus A., Emblematum libellus. Książeczka emblematów, tłum. A. Dawidziuk, B. Dziadkiewicz, E. Kustroń-Zaniewska, wstęp i oprac. R. Krzywy, Warszawa 2002.

Baran Z., Św. Jan Kanty w kulturze literackiej Polski przedrozbiorowej, w: Święty Jan Kanty. W sześćsetna rocznice urodzin 1390-1990, oprac. R.M. Zawadzki, Kraków 1991, s. 103-114.

Biblia w przekładzie księdza Jakuba Wujka z 1599 r. Transkrypcja typu „B” oryginalnego tekstu z XVI w. i wstępy ks. J. Frankowski, Warszawa 2000.

Bircovius F., Academicus catholicus, sive de b. Ioannis Cantii theologi, virtutibus catholicis, oratio, w: idem, Orationes ecclesiasticae, Cracoviae 1622, s. 311-326.

Bircovius F., Academica prima, sive de impedimentis bonarum litterarum, w: idem, Orationes ecclesiasticae, Cracoviae 1622, s. 469-480.

\footnotetext{
54 Idem, Staropolski konterfekt..., op. cit., s. 226.

55 G. Pico della Mirandola, Oratio de hominis dignitate. Mowa o godności człowieka, tłum. i przypisy Z. Nerczuk, M. Olszewski, wstęp D. Facca, Warszawa 2010, s. 47.
} 
Bircovius F., Academica secunda, sive de virtute acquirenda, w: idem, Orationes ecclesiasticae, Cracoviae 1622, s. 481-496.

Birkowski F., Kazania na niedziele i święta doroczne, Kraków 1628.

Birkowski F., Kazanie o ćwiczeniu młodzi przy pamięci b. Jana Kantego, akademika krakowskiego, w: F. Birkowski, Kazania obozowe o Bogarodzicy..., Kraków 1623, s. 71-86.

Birkowski F., Pierwsza mowa akademicka albo o przeszkodach $w$ dobrym kształceniu humanistycznym, w: idem, Mowy akademickie i polemiczne. Orationes academicae et polemicae, z języka łacińskiego tłum. B. Gaj, oprac. i komentarze B. Gaj, M. Rowińska-Szczepaniak, Warszawa 2016, s. 43-63.

Buszewicz E., Fragmenty wielkich (księgo)zbiorów. Okolicznościowe publikacje Kazimierza Fortunata Albrychowicza zwiazane z promocjami na Uniwersytecie Krakowskim, w: Monastycyzm XV-XVIII wieku. Tradycja średniowieczna wobec wyznań nowożytnego humanizmu, red. M.T. Gronowski, P. Urbański, Warszawa 2016, s. 271-297.

Clementis Divina Providentia Papae XIII Litterae decretales super canonizatione beati Ioannis Cantii presbyteri saecularis [promulgatae 16 VII 1767], wstęp W. Gasidło, tłum. R.M. Zawadzki, Kraków 2004.

Cyceron M.T., Pisma filozoficzne, cz.1, tłum. E. Rykaczewski, Poznań 1874.

Cyceron M.T., Pisma filozoficzne, t. 3, tłum. W. Kornatowski, komentarz K. Leśniak, Warszawa 1961.

Czerkawski J., Humanizm i scholastyka. Studia z dziejów kultury filozoficznej w Polsce w XVI i XVII wieku, Lublin 1992.

Dziennik oktawy na pamiątkę kanonizacji S. Jana Kantego..., w: J.A. Putanowicz, Życie, cuda i dzieje kanonizacji S. Jana Kantego..., Kraków 1780, k. Q-T2.

Erasmus D., Adagia, Leiden 1703.

Erazm z Rotterdamu, Adagia, wybór, tłum. i oprac. M. Cytowska, Warszawa 1973.

Gasidło W., Ku czci świętego Jana z Kęt w sześćsetlecie jego urodzin 1390-1990, Kraków 1991.

Graves R., Mity greckie, tłum. H. Krzeczkowski, wstęp A. Krawczuk, Warszawa 1974.

Hadrych Z., Kazania jako źródło informacji o świętych i epoce, „Archiwa, Biblioteki i Muzea Kościelne", 67/1997, s. 383-413.

Hernández de la Fuente D., Herkules w Hiszpanii: szkic o mitologii i symbolizmie, w: Prace Herkulesa - człowiek wobec wyzwań, prób i przeciwności, red. M. Cieśla-Korytowska, O. Płaszczewska, Kraków 2012, s. 75-86.

Jougan A., Homilie polskie od czasów najdawniejszych po dobę obecna. Szkice bibliograficzne i krytyczne, Lwów 1902, s. 198-245.

Kopaliński W., Stownik wyrazów obcych i zwrotów obcojęzycznych, Warszawa 1998.

Kosmana I., Homilia hagiograficzna pół wieku po „Vaticanum II”, „Studia Koszalińsko-Kołobrzeskie", 20/2013, nr 1-2, s. 73-83.

Koźluk M., Bivium virtutis et vitii - èthos Herkulesa w szesnasto- i siedemnastowiecznej ars emblematica, w: Prace Herkulesa - człowiek wobec wyzwań, prób i przeciwności, red. M. Cieśla-Korytowska, O. Płaszczewska, Kraków 2012, s. 59-74.

Kuran M., Barokowy kaznodzieja czyta rzymskich pisarzy (na przykładzie wielkopiatkowego kazania Mikołaja Szomowskiego , Raj niebieski na ziemi, potopem złości i okrucieństwa żydowskiego zniesiony...”), „Czytanie Literatury. Łódzkie Studia Literaturoznawcze”, 2012, nr 1, s. 189-207. 
Makowski A., Obraz wielebnego ojca Fabiana Birkowskiego z zakonu Dominika świętego doktora wystawiony na kazaniu pogrzebnym, Kraków 1636.

Marcjalis, Księga widowisk, tłum. K. Różycka-Tomaszuk, wstęp i komentarze A. Klęczar, M. Zagórski, współpraca B. Burliga, Wrocław 2015.

Mąsiorski F.B., Vita activa et contemplativa relata ad Cantianum dictum factumque „Ut supra”, brevi proloquio deducta..., Cracoviae 1771.

Miechowita M., Chronica Polonorum, Kraków 1521.

Niemirycz A., Ut supra, w: J.A. Putanowicz, Życie, cuda i dzieje kanonizacji S. Jana Kantego..., Kraków 1780, k. Eee-Fffv.

Okopień-Sławińska A., Relacje osobowe w literackiej komunikacji, w: Problemy socjologii literatury, red. J. Sławiński, Warszawa 1971, s. 109-125.

Panuś K., Chrystocentryczne przepowiadanie hagiograficzne, w: „Głosimy Pana Jezusa Chrystusa”. Treść przepowiadania, red. H. Sławiński, Kraków 2017, s. 261-280.

Pico della Mirandola G., Oratio de hominis dignitate. Mowa o godności człowieka, tłum. i przypisy Z. Nerczuk, M. Olszewski, wstęp D. Facca, Warszawa 2010.

Pismo Święte Starego i Nowego Testamentu w przekładzie z języków oryginalnych, oprac. zespół biblistów polskich z inicjatywy benedyktynów tynieckich, Poznań 1982.

Prejs R., Hagiografia polska. Najnowsze osiagnięcia, „Studia Nauk Teologicznych”, 6-7/2011-2012, s. 101-107.

Ranatowicz S., Jasna pochodnia życia apostolskiego..., Kraków 1660.

Rechowicz M., Swastek J., Jan z Kęt, w: Nasi święci. Polski słownik hagiograficzny, red. A. Witkowska, Poznań 1999, s. 293-305.

Rowińska-Szczepaniak M., Miejsce Fabiana Birkowskiego w dominikańskim „łańcuchu pamięci”, w: F. Birkowski, Mowy akademickie i polemiczne. Orationes academicae et polemicae, z języka łacińskiego tłum. B. Gaj, oprac. i komentarze B. Gaj, M. Rowińska-Szczepaniak, Warszawa 2016, s. 163-197.

Rowińska-Szczepaniak M., Mistrz i uczniowie. O etosie „,młodzi chrześcijańskiej” w świetle kazania Fabiana Birkowskiego, w: Na przełomie wieków... Studia i szkice ofiarowane Profesorowi Zdzisławowi Piaseckiemu w czterdziestolecie pracy naukowej, red. W. Hendzel, P. Obrączka, Opole 2003, s. 261-270.

Rowińska-Szczepaniak M., Sidus Cracoviensis Academiae. Łacińska mowa Fabiana Birkowskiego pochwała cnót Jana z Kęt, w: Teksty-konteksty-interpretacje. W kręgu literatury, języka i kultury, red. E. Dąbrowska, K. Kossakowska-Jarosz, Opole 2007, s. 121-129.

Seneca L.A., Listy moralne do Lucyliusza, tłum. W. Kornatowski, wstęp i przypisy K. Leśniak, Warszawa 1961.

Skarga P., Żywot błogosławionego Jana Kantego, doktora Akademiej Krakowskiej, Kraków 1667.

Skarga P., Żywoty świętych Starego i Nowego Zakonu, Kraków 1605.

Starowolski S., De claris oratoribus Sarmatiae. O znakomitych mówcach Sarmacji, wyd. i tłum. E.J. Głębicka, Warszawa 2002.

Szlagowski A., Żywot, charakterystyka i dzieła ks. Fabiana Birkowskiego, w: Mowy pogrzebowe i przygodne ks. Fabiana Birkowskiego, cz. 1, Warszawa 1901, s. 1-73.

Szomowski M., Raj niebieski na ziemi, potopem złości i okrucieństwa żydowskiego zniesiony abo kazanie na Wielki Piątek miane..., Warszawa 1655. 
Świerzawski W., Homilia hagiograficzna, w: Kanonizacje a nowa ewangelizacja. Sympozjum naukowe z okazji 30-lecia Instytutu Liturgicznego, Kraków 2000, s. 211-218.

Święcicka P., Proces Jezusa w świetle prawa rzymskiego. Studium prawno-historyczne, Warszawa 2012.

Tertulian K.S.F., Wybór pism, wstęp E. Stanula, oprac. W. Myszor, E. Stanula, Warszawa 1970.

Wargocki A., O Rzymie pogańskim i chrześcijańskim ksiag dwoje, wyd. J. Sokolski, red. J. Kroczak, Warszawa 2011.

Witkowska A., Polska twórczość hagiograficzna. Próba bilansu, „Anamnesis”, 11/2005, nr 40, s. 97-109.

Witkowska A., Nastalska J., Staropolskie piśmiennictwo hagiograficzne, t. 1: Stownik hagiografów polskich, Lublin 2007.

Zabłocka M., Pierwsza palingenezja ustawy XII tablic, „Prawo Kanoniczne: kwartalnik prawno-historyczny", 1993, nr 3-4, s. 149-155.

Zawadzki R.M., Św. Jan Kanty w świetle najnowszych badań, w: Święty Jan Kanty. W sześćsetna rocznice urodzin 1390-1990, oprac. R.M. Zawadzki, Kraków 1991, s. 7-24.

Zawadzki R.M., Spuścizna rękopiśmienna świętego Jana Kantego, Kraków 1995.

Zawadzki R.M., Staropolski konterfekt świętego Jana z Kęt, Kraków 2002.

Żrałko D., Biografia Fabiana Birkowskiego w świetle kazania pogrzebowego Adama Makowskiego i badań archiwalnych, „Pamiętnik Literacki”, 2005, z. 2, s. 215-227. 